\title{
The Chilika Lagoon Social-Ecological System: An Historical Analysis
}

\author{
Prateep K. Navak $^{1}$
}

\begin{abstract}
Innovations in social-ecological research require novel approaches to conceive change in human-environment systems. The study of history constitutes an important element of this process. First, using the Chilika Lagoon small-scale fisheries in India, as a case, in this paper I reflect on the appropriateness of a social-ecological perspective for understanding economic history. Second, I examine here how changes in various components of the lagoon's social-ecological system influenced and shaped economic history and the political processes surrounding it. I then discuss the two-way linkages between economic history and social-ecological processes to highlight that the components of a social-ecological system, including the economic aspects, follow an interactive and interdependent trajectory such that their combined impacts have important implications for human-environment connections and sustainability of the system as a whole. Social, ecological, economic, and political components of a system are interlinked and may jointly contribute to the shaping of specific histories. Based on this synthesis, I offer insights to move beyond theoretical, methodological, and disciplinary boundaries as an overarching approach, an inclusive lens, to study change in complex social-ecological systems.
\end{abstract}

Key Words: aquaculture; Chilika Lagoon; drivers; economic history; human-environment disconnection; India; livelihoods; marginalization; small-scale fisheries; social-ecological change; social-ecological systems; sustainability

\section{INTRODUCTION}

In this paper, I investigate change in small-scale fishery systems using the case of the Chilika Lagoon, on the Bay of Bengal, the largest lagoon in India and one of the largest in Asia. My main focus is on a series of ecological changes, under the influence of regional, national, and international drivers, that have had an impact on the social, cultural, economic, political, and environmental life of the fishers. To do this, I take an historical view of these changes, paying particular attention to the economic history of the area as that relates to lagoon social-ecological processes. Various components of (1) the social, e.g., political, economic, and cultural, and (2) the ecological, e.g., biophysical, geological, and hydrological, subsystems of small-scale fishery systems are integrally linked. They influence each other and act together to exert an impact on the system, forcing it to change. The study of history constitutes an important element in my approach. However, history can often be presented without the recognition that different components of a system are interlinked and may jointly contribute to the shaping of specific histories. Using a social-ecological view, the paper provides a short account of the historical background to the processes of change in the Chilika Lagoon fisheries. The paper investigates how these changes have influenced and shaped Chilika's economic history, which constitutes an integral part of the lagoon's social-ecological system. My primary focus here is on contemporary history spanning the second half of twentieth century, with selective references to some of the much older historical accounts dating back over the past two centuries.

\section{A social-ecological perspective for economic history}

The concept of marine social-ecological systems (SES) has recently gained prominence (Berkes 2011). It was developed from the idea that human societies and the biophysical systems that contain them are integrally linked (Turner et al. 2003, MEA 2005, Clark and Levin 2010, Christie 2011). It extends the analysis of social-ecological systems, highlights the integration of humans with nature, and considers any delineation between the two as artificial and arbitrary (Berkes and Folke 1998). Human actions affect biophysical systems and biophysical factors affect human well-being, which signifies the interconnected nature of the social, i.e., human, and ecological, i.e., biophysical, subsystems (Berkes 2011). Addressing only the social dimension of resource management, then, without understanding the resource and ecosystem dynamics, will not be sufficient to achieve sustainability and resilience in various components of a system (Folke et al. 2005, Charles 2007). This implies that both social and ecological processes define and shape the nature of changes in socialecological systems with social outcomes remaining contingent upon ecological dynamics and vice-versa.

However, systems thinking has been present in fisheries, as in other environmental and natural resource areas, for many decades, and its complex systemic nature is well recognized by scientists (Garcia and Charles 2008). Charles (1995, 2001, 2005) and his colleagues have recognized that systems thinking is longstanding, if not prominent, in the fisheries literature and precedes the body of work on social-ecological systems. Their work pertains to conceptualizing and implementing a fishery system approach comprising elements such as boundaries, hierarchies of scales, ecological, and human components, as well as a range of linkages and interactions that are crucial for sustainable and resilient fisheries (Garcia and Charles 2008). Related work has emphasized the importance of coastal community perspectives connected to the issues of community empowerment for integrated ocean and coastal systems management through an emphasis on public participation and multiple scales of governance (Charles et al. 2010). This has tremendous implications for understanding fishery and marine social-ecological systems. Although I recognize the role of systems thinking in facilitating work on social-ecological systems and a host of related work on fishery, coastal, and marine systems, the primary focus of my analysis will be on the use of a socialecological system perspective.

Social-ecological analysis recognizes the role of humans in shaping ecosystem processes and dynamics (Dale et al. 2000, Waltner-Toews and Kay 2005), thus valuing both their capacity to alter, and their vulnerability to, environmental change (Steffen et al. 2004, Halpern et al. 2008). This perspective offers a way to 
understand small-scale fisheries as complex systems (Mahon et al. 2008) because most of these social-environmental issues are complex, persistent or recurring, often hard to define or fix in a permanent way because of their larger ecological, social, economic, and political ramifications (Rittel and Weber 1973). Indeed, some scholars argue that fisheries and coastal governance together make up a 'wicked' problem (Jentoft and Chuenpagdee 2009, Khan and Neis 2010). A social-ecological perspective makes it possible to look at multiple levels of analysis, multiple realities, and therefore, provide multiple ways of understanding complex SES problems (Nayak 2011), including those known as wicked. It helps researchers to look beyond issues either in the social or ecological domains and examine many related elements in the two component subsystems, i.e., (1) economy, culture, institutions, and politics within the social subsystem and (2) biotic and abiotic processes representing food web, and geological, hydrological, and climatological features of the ecological subsystem. Focusing on these subsystems as distinct parts of the larger socialecological system also promotes the development of their understanding, because they are valued as integral to each other, i.e., bound as a coupled system (Turner et al. 2003, Glaser 2006, Kotchen and Young 2007). Thus, it compels researchers to look beyond theoretical, methodological, and disciplinary boundaries to offer an overarching framework, an inclusive lens, to study complex social-ecological systems.

A growing body of literature supports the idea that local fisheries can be understood as integrated social-ecological systems (Ommer 2007, Mahon et al. 2008). Here, social-ecological and human-environment are used as essentially equivalent. Thus, 'social' is meant to cover human and vice versa. It seeks to highlight the reality that 'social' actually has a narrower meaning in some uses and emphasizes the need to also include economic and political, not only social, aspects to cover all the human dimensions of the system. Overall, the term social-ecological system is used in a manner synonymous to human-environment system. I highlight the crucial importance of the economic dimension within the social-ecological system, including its influence in terms of drivers, objectives, and dynamics. The economic aspects of these fisheries can also be seen as clearly linked to their ecological and social counterparts. Socialecological systems have many drivers, an array of impacts, unpredictable ways in which drivers act, uncertain system dynamics, and two-way feedback interactions between human and biophysical systems (MEA 2005). To understand the complexities involved, one has to consider all of the factors together because analysis of social-ecological systems generally differ from analysis of the social or ecological subsystem alone (Ludwig et al. 2001, Westley et al. 2002).

Drivers, defined as any natural or human-induced factor that directly or indirectly causes a change (MEA 2003, 2005), are a good way to understand this linkage. Irrespective of their source of origin and scale, both temporal and spatial, of operations, drivers have an impact on all sectors either directly or through a process of cascading effects. A single driver can potentially have an impact on a cross-section of aspects within the socialecological system, i.e., social, economic, political, cultural, institutional, biophysical, and environmental, with perceivable variations in the intensity of impact on the different components of the social-ecological system. A combination of different drivers can also have similar impacts: an economic or ecological driver will not only have an impact on the economic or the biophysical components of the system, respectively. Thus, a global economic driver, such as globalization or international market shifts, can potentially influence other aspects of the system, including the ecosystem. Likewise, climate change as a global driver may have a similar influence on local and regional economies, through the altering of livelihood systems and the distortion of the basis of the system's ecological economics. The study of drivers, then, reinforces the idea that economy cannot be logically separated from other components of the social-ecological system. Instead, it constitutes an integral part of it (Perrings and Walker 1995, Holling 2001, Walker et al. 2002). However, the economic history of local fisheries is often presented in isolation from social and ecological histories and vice-versa (Daily 1997, Crocker 1999, Gómez-Baggethun et al. 2010). Considering the economy as a part of the social subsystem and linking economic aspects with the rest of the social-ecological system is important. It allows researchers to creatively address change in human-environment systems and point the way forward to sustainability.

\section{METHODS}

This case study reviews the recent economic history of the Chilika Lagoon small-scale fisheries and links it to its social-ecological history. Connected to the Bay of Bengal on the south, with the Eastern Ghats Mountain ranges forming most of its catchment on the north and the west, Chilika is a Ramsar Site of international conservation importance and a biodiversity hotspot (Fig. 1). Some rare, vulnerable, and endangered species listed on the International Union for the Conservation of Nature's (IUCN) Red List of threatened animals inhabit the lagoon. It is the largest wintering ground for migratory waterfowl found anywhere on the Indian subcontinent and home to Irrawaddy dolphins (Orcaella brevirostris). The total number of fish species is reported to be more than 225 . Along with a variety of phytoplankton, algae, and aquatic plants, the lagoon region also supports over 350 species of nonaquatic plants. A phytodiversity survey has identified 710 plants in Chilika (Pattnaik 2003). A survey of the fauna carried out by the Zoological Survey of India in 1985-87 recorded over 800 species in and around the lagoon. This list includes a number of rare, threatened, and endangered species, including the Barkudia limbless skink.

Fig. 1. Location of Chilika Lagoon, Odisha, India.

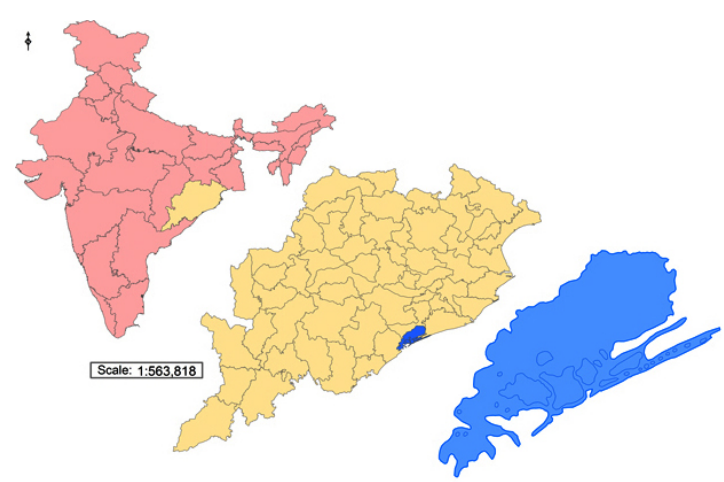


Chilika's biodiversity is also an integral part of sustaining the culture and livelihoods of about 400,000 fishers and their families, who belong to specific caste groups and live in more than 150 villages. The fishery consists of traditional fisher groups whose vocation is identified by their membership in certain Hindu castes (Nayak and Berkes 2011): there are seven different types of fisher castes and five subcastes in Chilika (Table 1). The lagoon ecosystem also indirectly supports 0.8 million nonfisher higher caste, e.g., Brahmins, Karans, Khandayat, and Khetriyas, villagers in the watershed areas, whose occupants traditionally engaged in farming, forestry, and other livelihood occupations. However, owing to large-scale forest and land degradation, subsistence based on agriculture and forests is on the decrease. Consequently, a number of nonfisher caste members have now turned to aquaculture, and in some cases regular capture fishing, as a growing source of income. This is part of a growing trend: many fisheries in India, once dominated by traditional fishers, their community, and caste organizations (Nayak and Berkes 2010), are now increasingly under pressure from the influx of new groups (Lobe and Berkes 2004, Coulthard 2008), and Chilika is no exception.

Data came from a larger study that focused on understanding the processes of change in the Chilika Lagoon fisheries and fishers' marginalization through disconnection from the lagoon. The study was carried out over a period of 28 months during 2007-2009 using a mixed methods approach. Both qualitative and quantitative methods were employed, governed by the broad principles of participatory approaches. Household data came from two villages, Berhampur and Badakul, located in the Puri and Khurda districts of the Odisha State, respectively (Fig. 2). These villages were chosen on the basis of caste composition, rate of encroachment on customary fishing areas, impact of shrimp aquaculture, loss of fishery-based livelihoods, rate of outmigration, and status of village fishery institutions. Village surveys $(\mathrm{N}=140)$ and household surveys $(\mathrm{N}=160$ in two villages) were combined with semistructured interviews and focus groups with multiple actors. Household-level $(\mathrm{N}=30)$ livelihoods were monitored monthly in Berhampur and Badakul over an 18-month period. Opinions and perceptions of fisher villagers were gathered as part of the general village survey $(\mathrm{N}=140)$ in which groups of adults, ranging from 20 to 150 per village and comprised of either the larger village committee or its general assembly depending on village size, filled out a survey questionnaire. I carried out all the interviews and focus groups in my role as the principal research investigator. One full-time and one part-time community researchers were recruited from local fisher villages, and they were trained to assist with the household and village surveys and in conducting household-level monthly livelihood monitoring. Additional help was obtained from the Chilika Fisher Federation in completing the village surveys.

Several community consultations and workshops were organized to follow up on findings. Interviews with the members of the village institutions were conducted, and focus group discussions were held to elicit views of women and other vulnerable groups. The views of NGOs, bureaucrats from relevant government departments, political representatives, fish traders, officials of the tourist boat associations, and representatives of the fishers' federation were collected, so that I could understand the perceptions of a cross-section of stakeholders. Four one-day policy workshops were organized with selected village representatives. Over the research period, interviews, focus groups, and other participatory exercises had representatives from over 70 percent of the households in Berhampur and 100 percent of the households in Badakul. A number of these exercises were also conducted in Chilika, outside the two study villages and included both fisher and nonfisher villages. A wide variety of secondary data sources were also accessed including written village records, account books of fish traders, records of tourist boat associations, and proceedings of the fishers' federation. Village historical records from the fisheries department on fishing area lease rights going back to 1957 were collected and analyzed. I also referred to government orders, legislative assembly proceedings, development plans, and other policies concerning lagoon management at the district, state, and national levels.

Fig. 2. Location of study villages, Berhampur and Badakul, in Chilika Lagoon.

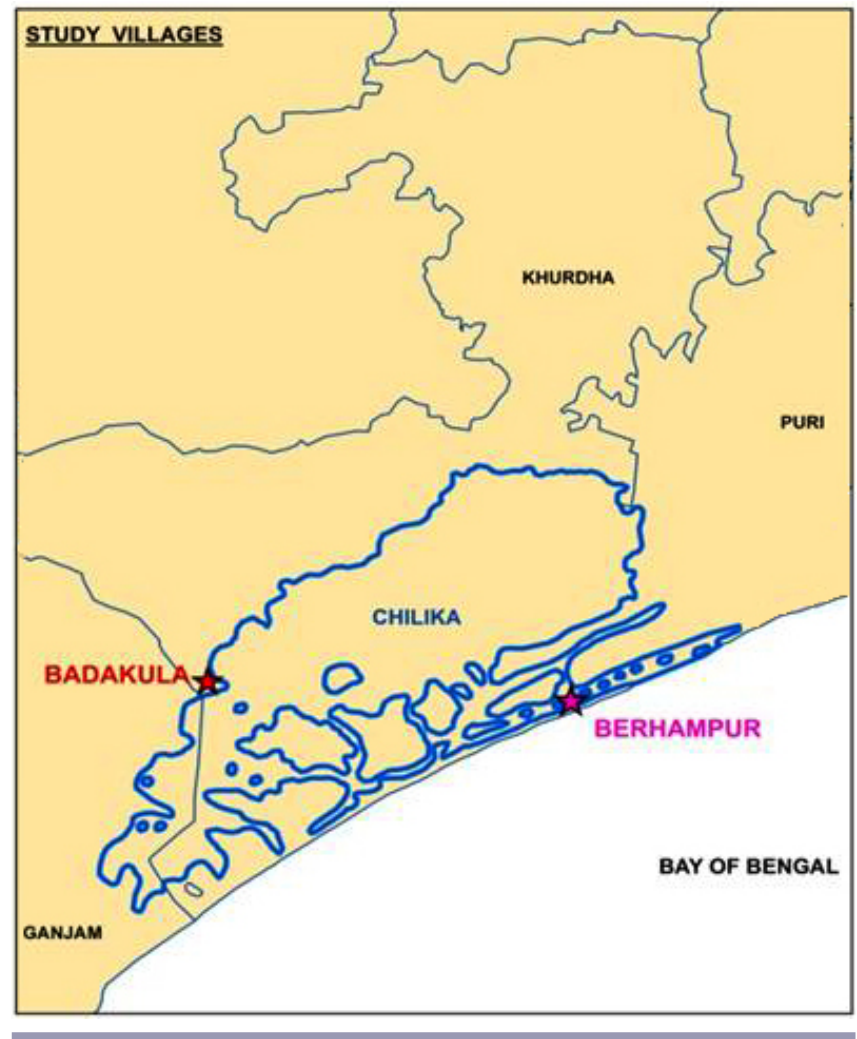

\section{RESULTS}

\section{Chilika throughout History}

\section{Preindependence Chilika}

Geologically and ecologically, the origin of the Chilika Lagoon was more than a million years Before the Common Era (BCE). Although we cannot be certain, human interaction with the lagoon appears to be relatively recent, dating back a few hundred years according to documentary evidence, but may go back as far as a few thousand years ago if we consider descriptions in the 
Table 1. Profile of fisher caste groups in Chilika.

\begin{tabular}{|c|c|}
\hline $\begin{array}{l}\text { Fisher castes and } \\
\text { groups }\end{array}$ & Profile \\
\hline $\begin{array}{l}\text { 1. Keuta or } \\
\text { Kaibartya }\end{array}$ & $\begin{array}{l}\text { Largest group in Chilika; mostly educated; live on all sides of the lagoon; occupy the top in the fisher caste } \\
\text { hierarchy. }\end{array}$ \\
\hline 1.a. Dewar & Live on the east and west side; traditionally rowed commuter boats but later took up fishing as main \\
\hline Kaibartya & occupation. \\
\hline $\begin{array}{l}\text { 1.b. Hula Hania } \\
\text { Keuta }\end{array}$ & Live on the west side; use a variety of gear to focus on specific fish species; fish mostly during night. \\
\hline 1.c. Bilua Keuta & Use a variety of nets and fish in groups by making sounds like a fox (bilua) to divert the fish to the nets. \\
\hline 1.d. Chudutia or & Customarily prepared pressed rice (chuda) for the world famous Puri Jagannath temple; were primarily \\
\hline Chudakuta Keuta & $\begin{array}{l}\text { engaged in small grocery businesses and farming; in recent times fully engaged in fishing and fish related } \\
\text { activities. }\end{array}$ \\
\hline 1.e. Kaibartya & $\begin{array}{l}\text { Customarily engaged in making all types of boats for lagoon fishers; now fully engaged in fishing and fish } \\
\text { related activities. }\end{array}$ \\
\hline 2. Niari or Liyari & $\begin{array}{l}\text { Very few in numbers; customarily prepared puffed rice (liya and } u k h u d a \text { ) and sold at the fish landing sites and } \\
\text { fish markets; engaged in fishing of anchovy (patua). }\end{array}$ \\
\hline 3. Karetia & $\begin{array}{l}\text { Live on the west side of Chilika but their fishing areas are mainly on the east side; used handmade cotton nets } \\
\text { but recently moved to nylon/synthetic nets. }\end{array}$ \\
\hline 4. Gokha & $\begin{array}{l}\text { Very few in numbers; live on east side of Chilika; customarily used khadi-jala (nets) and khepa-jala (nets) but } \\
\text { have shifted to nylon/ synthetic nets. }\end{array}$ \\
\hline 5. Khatia or Katia & $\begin{array}{l}\text { Located on the east and west side of Chilika in large villages; primarily use drag nets; economically better off; } \\
\text { their caste panchayat includes nine villages (known as Naa-desha or nine nations) within which all their } \\
\text { marriages take place. }\end{array}$ \\
\hline 6. Kandara & $\begin{array}{l}\text { Second largest fisher caste group and at the bottom of fisher caste hierarchy; live all around the lagoon; } \\
\text { primarily use different types of traps made out of bamboo for fishing; fish different types of prawns. }\end{array}$ \\
\hline 7. Tiara & Live on the east and west side of the lagoon; use bamboo made traps for fishing. \\
\hline
\end{tabular}

Source: Adopted from Nayak (2011)

ancient Hindu religious texts and local legends (Das 1977, Pattanâyaka 1979). Recent archaeological excavations, including radiocarbon dating, also give evidence of the existence of human society and culture, maritime trade activities, and boat building in Chilika as far back as 2300 BCE (Patra and Patra 1993, Sinha 2000). Regardless of when they might have originated, the caste norms and rules are considered to have been the initial basis for property rights regimes in Chilika (Nayak and Berkes 2011). These rules clarified fishers' access in terms of who could fish where, when, what species and size of fish, and how much. The rules had varying degrees of state recognition, both in the preand postindependence periods.

Even though part of the history of the development of property rights in Chilika is untraceable, documented but unpublished local histories offer recorded evidence that the formalization of fishers' access and use rights took place as far back as the late 1500s (Ray 1960, 1981). Oral history suggests that during both the Mughal and Maratha rules, fishers' access to the lagoon fisheries were regulated by the king. In subsequent periods, fishers were able to exercise their fishing rights over the 'sairats,' i.e., fishing grounds, by paying 'bheti' or 'salami,' i.e., tributes or gifts in kind, to the king and the 'zamindars,' i.e., landlords in charge of tax collection, to obtain permission, or a license. This practice began in 1790 and continued until the British colonial government took over the fishing activities in Chilika in 1930. Although the state of Odisha came under British rule in 1803, a British company controlled revenue administration in Chilika, and ownership of the lagoon remained with the King of Parikuda until about the beginning of the 1900s (Pattnaik and Mehrotra 2006).

In 1880, British Surveyor J. H. Taylor recorded that all fishing rights over the lagoon belonged to the fishers. Subsequent British settlement of the state of Odisha (1897-98) also recorded exclusive enjoyment of fisheries in Chilika by the caste-based fishers. However, the ownership of the lagoon remained with the Kings of Parikuda, Khallikote, and Palur, who administered the fisheries of Chilika through the zamindars of Khallikote, Parikuda, Suna Bibi, Mirza Taher Baig, the Chaudhary families of Bhungarpur, and the Khas mahal areas of Khurda. The zamindars leased out the fisheries exclusively to the caste-based fishers for customary fishing activities and collected lease rents for the fishing sairats, i.e., the fishing ground or fishery sources defined by location and species for lease and tax purposes. This started a more formal lease system for apportioning fishing rights in Chilika that continues even today. The British started a cooperative store in Balugaon in 1926 to sell fishing equipment to local fishers and also created 25 Primary Fishermen's Cooperative Societies (PFCS) during the Second World War. Together these elaborate administrative and policy arrangements were the foundation of a more formal fishing economy in Chilika. 


\section{Postindependence developments}

Early changes in policy making

Following India's independence, the zamindari system and the Zagir Mahals were abolished in 1953. Zagir was the assignment of lands by the sovereign to persons of distinctive merit and subordinates. Mahal was the fiscal unit into which the whole land or area was divided for purposes of revenue collection, thus Zagir Mahal represented a formal revenue unit. The revenue department of the government of Odisha took charge of the Chilika fisheries and continued the lease system through open auction during 1953-1959. This marked the beginning of direct bureaucratic control of the fishing areas and is an identifiable first step toward turning Chilika fisheries into state property. In 1956, the state government brought in legislation establishing its complete ownership of the lagoon. However, as Chilika formally went on record as being state property, the fishery resources, which had been continuously accessed and used by the fishers since the time of the Mughals or even prior to that period, became known as 'customary' fishing areas. The state of Odisha continued a supportive relationship with Chilika fishers for about three decades. In a set of proactive policies in 1959, a Central Fishermen's Cooperative Marketing Society (CFCMS) was created, with a number of village-level Primary Fishermen's Cooperative Societies (PFCS) as members. The revenue department began to administer fishing area leases to the PFCSs, using the CFCMS as a fishers' apex organization. This arrangement not only recognized fishers' continued access to their customary fishing areas but also allowed the fisher organizations to retain decision-making power with regard to such access.

The post-1960 period, however, witnessed a number of policy and institutional changes that threatened fishers' access and commons rights and influenced their economic activities around fishing. The first step was the introduction in 1965 of a $10 \%$ annual increase in the existing lease fees, followed by a 1978 government order that doubled the lease fees. Less than a decade later, the government of Odisha closed down the CFCMS and created a state agency known as the FISHFED, an apex institution of Primary Fishermen Cooperative Societies in the state, to replace it. That done, the 1988 policy of having three-year leases was changed to one year only. Fishers had preferred a three-year lease because they could make long-term plans and finalize business deals with fish traders without having to spend time and money preparing the annual paper work required to obtain their leases. Moreover, they complained that a strong aquaculture lobby, which objected to any long-term leases to fishers, influenced the government lease decision. Out of a total of 88 responses, 81 lease holding fisher villages reported some or total loss of their fishing lease areas during my survey in 2007-2008, either through government policy changes or aquaculture encroachments.

Controversies around the lease policy of 1991 and changes in institutional hierarchies

At the beginning of 1990s there was a consolidation of economic liberalization processes and a formalization of neoliberal policies in India. In Chilika, the pressure on emerging capital to invest in shrimp aquaculture became intense. The government was required to facilitate capital investment in the lagoon and contribute to the expansion of the national economy through export revenues. Consequently, in 1991 the State Government introduced a new policy that became a landmark piece of legislation because: (1) it created aquaculture resources for the fishery in Chilika, in addition to the customary capture practices of the caste-based fishers, and (2) it further increased the annual lease fee by $27 \%$ and made it mandatory for the lease to be administered by the FISHFED. Thus, the 1991 policy, which had symbiotic linkages with the formal acceptance of neoliberal economic policies by the country in that same year, legalized shrimp aquaculture in Chilika and made provisions for nonfisher caste villages to engage in it. Moreover, the $27 \%$ increase in the annual lease fee meant that it doubled in less than three years. Such an enormous lease fee was not affordable, because according to general reports from surveys and interviews, fish production had plunged, bringing down fishers' income levels and forcing many to outmigrate. Because the village-level fisher cooperatives went out of business, the entire burden of the lease fee fell on the remaining fishers who found it difficult to renew their leases.

Fisher cooperatives challenged the 1991 policy in the Odisha State High Court. After prolonged legal battles, the High Court in 1993, the Supreme Court of India in 1996, and the Odisha State Legislative Assembly House Committee in 1997 banned shrimp aquaculture, and the customary access and use rights of castebased fishers in Chilika were upheld by all three. In 2001, the State Government banned shrimp aquaculture in the lagoon and cancelled the 1991 lease policy. However, to this day illegal shrimp aquaculture continues unabated and significant portions of leased areas continue to be encroached upon. This gap between higher court rulings and their implementation on the ground results from the lack of accountability of those institutions whose task it is to do the implementing, and it highlights the clout of capitalists in the Odisha ruling class.

In addition to FISHFED, another centralized autonomous agency known as the Chilika Development Authority (CDA) was created under the State Forest and Environment Ministry in 1992. Under the CDA, management of the lagoon became strictly centralized and gradually saw the decline of several existing institutions, such as the traditional village committee, PFCS, 'Jati Panchayats,' or Caste Assemblies, and the Fisher Federation, which once offered a strong foundation for the fishers to engage in livelihood and economic activities in the lagoon.

2001 Regulation of fishing in Chilika

In 2001, another controversial bill, known as the Odisha Fishing in Chilika (Regulation) Bill, was brought before the State Legislative Assembly. Although it had many positive elements, one controversial provision in the bill overshadowed all the rest. The bill promised to reserve $30 \%$ of the lagoon fishing area for nonfishers, referring to those who were not in the castes/subcastes associated with fishing in the past, whereas the PFCSs were entitled to lease the other $70 \%$. Although this may seem like a bias in favor of traditional fishers, the clause virtually sanctioned the illegal encroachment of the lagoon's waters by the shrimp lobby and gave nonfisher groups a legal claim (Pattnaik and Mehrotra 2006) to the lagoon. Customary fisher leaders worried that if the bill retained this clause after enactment, the nonfisher groups would get the legal backing they needed to continue to encroach upon customary fishing grounds. They suggested that by allowing fishing rights to nonfishers, the State Government was indirectly promoting illegal shrimp farming. This would 
threaten the livelihoods of customary fisher communities, further impair the local fishing economy, and cause damage to the fragile Chilika ecosystem.

\section{Multilevel drivers changing the course of history}

Several drivers contributed to the process of social-ecological change in Chilika and influenced the shaping of the lagoon's history. However, two major drivers stood out. One was the growth of shrimp aquaculture in the 1980s, which led to questions about access, usage rights, and changes in the rules of the game in the lagoon fish economy. The second was the opening of a new sea mouth to the Bay of Bengal in 2001, which has had a direct impact on biophysical processes and, by extension, associated livelihood systems. Even though the two drivers followed distinctly different temporal scales, their cumulative impacts have been felt in the Chilika social-ecological system, which includes the lagoon and the fisher communities. However, focusing on the two drivers does not preclude the role of other drivers in Chilika and the multidirectional impacts of both relative stasis and relative change.

\section{Shrimp commercialization and explosive aquaculture}

The first instances of commercialization of the fisheries in Chilika can be traced back to British control of the lagoon in the year 1930. Kolkata, then Calcutta, became the central market place for Chilika fish, which was frequently transported by road and sea. The fish trade became international with the advent of the Second World War, and processed dry fish from Chilika was regularly exported to Rangoon, present day Mayanmar (Desai 1961, Patra 2005, Pattnaik and Mehrotra 2006).

Growing consumer demand in North America, European countries, and Japan escalated international prices (Neiland et al., 2001, Bene 2005), and that eventually became a major motivation for countries in the south to adopt export-oriented shrimp aquaculture. The international market for shrimp and prawn initially developed in the 1970s, and in India, its commercialization and scientific farming started in the 1980s. Prawns in India, which previously had little value, became 'pink gold' (Kurien 1992). That in turn prompted the development of shrimp aquaculture, which started intensively in the late 1970s in India and gained momentum in the mid-1980s, putting India among the leading shrimp exporting countries in the world. The total value of export earnings from shrimp in the year 2004 was US\$715 million (FAO 2006). In terms of its contribution to exports, increased production contributed over $32 \%$ by volume (18,300 MT) and 49\% by value (US\$40 million) during 1988-1989 (Vasudevappa and Seenappa 2002). During 2001-2002, cultured shrimp contributed $59 \%(74,826$ MT) by volume and $85.80 \%$ (US\$631 million) by value of total exports; a 3-fold increase in volume and over 14 folds in value (Vasudevappa and Seenappa 2002; K. J. Cyriac, unpublished report). Such high levels of production were prompted by a steady increase in the global demand for seafood and a consistent decline in the yield from capture fishery (Marshall 2001, Delgado et al. 2003, Pradhan and Flaherty 2008). Originally a natural area for tiger shrimp, (Penaeus monodon), Chilika Lagoon also caught on to the trend in the early 1980s, as investors and policy makers found the lagoon highly suitable for intensive shrimp aquaculture (Nayak and Berkes 2011). Soon shrimp aquaculture became a major driver of change there; its development spreading rapidly and intensively throughout the lagoon (Nayak and Berkes 2010).
Sea mouth creation and changes in Chilika's social-ecological system (SES)

Sea mouths are an important feature of coastal lagoons. In Chilika, oral history records about seven sea and river mouths that helped create the distinctive character of the lagoon in which marine, freshwater, and brackish water environments are found in different locations. Sea mouths do close down naturally, and Chilika had lost most of its sea mouths by the twentieth century. Bengal District Gazetteers, in 1908, refer to a single functional mouth into the Bay of Bengal (O'Malley 1908). Post-1970, this sea mouth was not sufficiently functional to facilitate the flushing of sediments and silt from the lagoon into the Bay of Bengal, resulting in the need for a more functional opening with the sea, and so a new mouth was dredged in 2001 (Chilika Development Authority, 2007, personal communication).

However, popular wisdom gathered through focus groups and household surveys in 2007-2008 had been in support of the renovation of the old mouth, and not surprisingly, within weeks of dredging completion there were several adverse impacts. In contrast to the old sea mouth where the daily inflows and outflows had been buffered by the presence of channels and islands, the new sea mouth, efficiently engineered to flush out sediments, also allowed in too much sea water with inadvertent ecological and livelihood impacts (Nayak and Berkes 2010). In the two study villages, none of the fisher households identified any positive impacts of the new sea mouth. All households in Berhampur said they had been negatively impacted. In Badakula, only 35\% indicated negative impacts, but they did not feel that there were positive impacts either. Fisher village location in relation to the sea mouth was a major factor in the differences between the two villages' responses. Nevertheless, all fisher households agreed that the lagoon condition was deteriorating and fish production had gone down. Not all of them clearly linked these changes with the sea mouth; many of them had not even seen the sea mouth because they were some distance away from it. However, based on their real-life experience and proximity to other drivers of change, these fishers were able to link the adverse changes in the lagoon condition to aquaculture activities and to the deteriorating condition of river channels, the freshwater sources of the lagoon. Some even blamed massive forest degradation in the catchments.

\section{Changes and impacts across Chilika's social-ecological system (SES)}

The preceding discussions on the two major drivers of change in Chilika, i.e., growing aquaculture and sea mouth alteration, suggested a wide variation in the temporal scale of their occurrence and impacts. Aquaculture operations began in the late 1980 s, and the sea mouth intervention was done in the year 2001. Thus, social-ecological changes associated with aquaculture were on a different time scale, developing over several decades, than changes linked to the sea mouth opening of the lagoon to the ocean. As Figure 3 shows, aquaculture acted as one of the major drivers causing change in Chilika from the 1980s until about the year 2000. During the period following 2001, the sea mouth opening to the ocean became a major driver and had an impact on the lagoon system. However, the effects of aquaculture did not cease with the onset of the impacts from the sea mouth. Instead, the two drivers acted synergistically, the sea mouth impact amplifying fisher livelihood disruption caused by aquaculture expansion, and the two together resulted in the two major outcomes, i.e., loss of livelihoods and outmigration (Nayak and 
Table 2. Fishers' strategies to deal with livelihood crisis.

\begin{tabular}{ll}
\hline \hline Livelihood strategies & \multicolumn{1}{c}{ Specific activities } \\
\hline Coping for subsistence & $\begin{array}{l}\text { Take loans and credit; mortgage and sell household assets; change in food habit; discontinue } \\
\text { children's education; rearrange personal and professional relationships. }\end{array}$ \\
Change gear selection and use; stop following fish seasonality; apply no size restriction on \\
catch; no time and space (fishing area) restriction; no restriction on species to catch; focus on \\
single species based on availability and price; intensive aquaculture. \\
Travel long distances for fishing; capture strategic areas for fishing; look beyond the lagoon, i. \\
e., collection of sea fish by traders; catch all available species; production extensification such \\
as selling freshwater fish; target nonfish species; fish by organized groups; extensive \\
aquaculture. \\
Diversify activities within fishing sector, i.e., employment as boat driver; develop nonfishing \\
occupations, i.e., daily wage; engage women and children in income generation activities. \\
Migrate long term; migrate seasonally or rotationally; migrate within the province; migrate \\
Migration
\end{tabular}

Berkes 2010). In the rest of this section, I analyze impacts of the two drivers by focusing on (1) the shifts in ecosystem processes, (2) social, economic, and livelihood crises, and (3) changes in institutional and political dynamics and the descriptions of the social-ecological changes cover a time scale associated with the occurrence and continuation of both aquaculture and sea mouth in Chilika.

Fig. 3. Temporal scale of occurrence of drivers, Â aquaculture and sea mouth, $\hat{A}$ and their impact on outmigration in Chilika fisher villages.

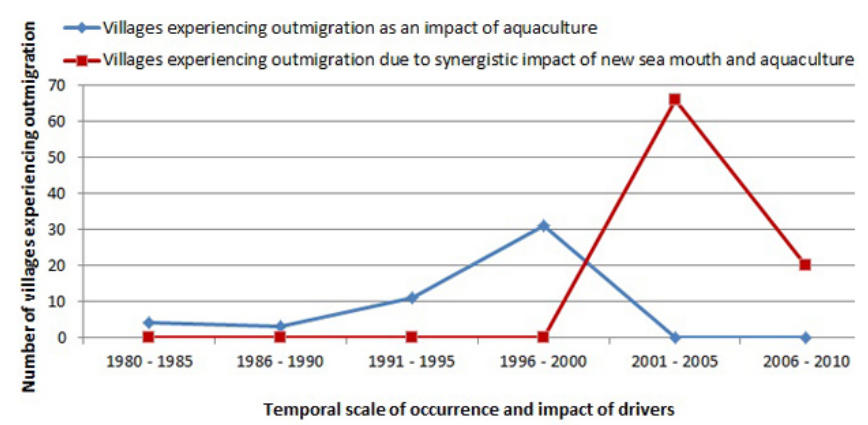

\section{Shifts in ecosystem processes}

Coastal lagoons are unique because of their interaction with marine, freshwater, and terrestrial catchment systems (Rana et al. 1998). The habitats they offer and the biodiversity they nurture are also distinctive. Lagoons have discrete biophysical processes and distinctive seasonalities. Lagoon-dependent human interactions take these specialties into their social, cultural, and economic practices and largely remain sensitive to fluctuations in lagoon ecosystems. In Chilika, the fine balance between the ecological and social subsystems became disturbed when aquaculture activities commenced in the 1980s and the sea mouth was altered in 2001, followed by the combined impacts of both thereafter.

The ecological subsystem, i.e., the lagoon ecosystem, came under stress from the adverse impacts of the two drivers. Habitats of most key species of fish, crab, and shrimp, along with associated species such as Irrawaddy dolphins (Orcaella brevirostris) and migratory birds were reportedly damaged. Fluctuations in the main biophysical processes led to a change in species composition and altered food webs in the lagoon. Locally extirpated fish, according to fishers, included a total of 11 species that were once commonly available in the lagoon, and several of them were moderate to high market-value species, which constituted a 'strength' of the fish economy. Such loss of fish biodiversity might be expected, not only from the impacts of hydrological change, but also from extensive aquaculture operations, which turned species-rich areas into monocultures (Nayak and Berkes 2012). Nayak and Berkes (2010) recorded six important changes in the lagoon ecosystem: (1) disturbance of the salinity regime and the fresh water-salt water balance; (2) changes in the nature of the water inflow and outflow during high and low tides; (3) an increase in sand infestation, especially in the lagoon's outer channel areas near the new sea mouth; (4) random changes in the depth of the water; (5) invasion of barnacles affecting both fishers and their equipment; and (6) the sudden appearance of what local people call sea creatures, i.e., stingray (Trygon sephen), octopus (Cabreana octopus), jelly fish (Cnidaria scyphozoa aurelia), and others. The most significant impact of these changes was felt through an increase in the variability, uncertainty, and unpredictability of events associated with the lagoon, such as fishing seasons for species, with impacts on fish production and livelihoods.

\section{Social, economic, and livelihood crises}

True to its character as an integrated social-ecological system, changes in the lagoon ecosystem had far reaching consequences for the social subsystem of Chilika. Fish production reached an all-time low during 2007-2010, and the small-scale fish economy, efficiently run by caste-based fishers and their organizations for centuries, began to collapse. I estimated the loss of productivity through several methods, including visual estimation, i.e., photo and video documentation, of daily catch size, fish collection records of village fish traders, and periodic fish catch by households, which I obtained through household surveys and monthly monitoring. Household level incomes dropped, clearly as a result of the decline in fish production. Overall, a major outcome was the loss of fishery-based livelihoods. Fish yields and 
Table 3. Major changes in institutional arrangements in Chilika.

\begin{tabular}{ll}
\hline \hline Key changes & \multicolumn{1}{c}{ Implications } \\
\hline Incapacitation of local institutions & $\begin{array}{l}\text { Higher level institutions (CDA, FISHFED) have become powerful either by taking } \\
\text { over existing power structures or creating new levels of authority for themselves. } \\
\text { Lower level institutions, i.e., village cooperative, CFCMS, Chilika Fisher Federation, } \\
\text { have lost capacity and been eliminated in the process. }\end{array}$ \\
$\begin{array}{l}\text { Top-down institutions replacing bottom-up } \\
\text { processes }\end{array}$ & $\begin{array}{l}\text { Accumulation of institutions at higher levels have suppressed the legitimacy of } \\
\text { existing community-level institutional arrangements. } \\
\text { Institutional vacuum } \\
\text { Disappearance of several institutions, i.e., village cooperative, Caste Panchayats, } \\
\text { Chilika Fisher Federation, representing different levels and the absence of institutions }\end{array}$ \\
$\begin{array}{l}\text { Loss of linkages between institutions, } \\
\text { at certain levels. } \\
\text { institutions }\end{array}$ & $\begin{array}{l}\text { Lack of linkages between institutions across levels and missing linkages between } \\
\text { institutions, e.g., government and community-level nongovernment, along with } \\
\text { dominance of higher level organizations on lower level institutional arrangements. }\end{array}$ \\
\hline
\end{tabular}

fisher incomes both declined because of the combined impacts of the two drivers, seriously enough to make fishing livelihoods no longer viable in some villages, with negative trends in all fisher villages (Nayak and Berkes 2010).

Field study recorded several livelihood strategies adopted by Chilika fishers to deal with the rising livelihood crisis. Table 2 shows the five groups of strategies employed; a strong indication that the local subsistence and household economy was under stress. Severe food insecurity in fisher communities became evident, increasing fishers' dependence on staggering amounts of cash loans. A food culture that had been predominantly based on rice and fish and that blended well with the lagoon socialecological system and fishing economy, virtually collapsed. Contributing to this collapse of food culture was a dramatic rise in the cost of rice and other food items, in general. In the two study villages, Berhampur and Badakul, $100 \%$ of the households were dependent on cash loans; the mismatch between household income and the amount of the loan reflected fishers' inability to repay. Interest rates of $60-120 \%$ per annum added an additional burden. A significant number of households in both villages took their children out of school to minimize costs and to engage them in income activities. I recorded, from the school records, high dropout rates, $51 \%$ and low enrolment, $39 \%$, in the village school of Berhampur, and a 70\% fall in students appearing for the high school examination during 2007-008. As per the school records for earlier periods, these figures are significantly higher than the previous years.

Intensification and extensification strategies resulted in customary fishing practices being replaced by the use of exceptionally catch-intensive fishing gear, which allowed the fishers to increase their fishing efforts by avoiding customary restrictions on seasonality, i.e., time, fishing locations, fish species, and size. Over several fishing trips with local fishers, I confirmed that up to $40 \%$ of the catch consisted of immature fish and crabs (2007-2008). Several households engaged in postlarval shrimp harvest. Shrimp aquaculture also caused serious loss of capturefishing areas. As a result, both intensification and extensification activities not only led to an adverse impact on fish stocks, biodiversity, and lagoon biophysical processes, but also risked future economic benefits from the lagoon.
Migration not only brought physical separation of the fishers from the lagoon, but also initiated a set of cascading effects. More than one-third of adult fishers and their families were occupationally displaced from fishing and had either migrated to urban centers as unskilled workers or taken up daily wage labor (2007-2009). Although only men migrated, the costs for the families who sent them were far reaching. In the absence of men, the household stopped fishing because culturally it was only the men who fished. Women in the households then had to discontinue their fish processing chores, which had been empowering both economically and socially within the smallscale fisheries sector. Diversification activities forced fishers to alienate themselves from fishing both as a part of their caste identity and as a culture that built and sustained a sense of community. Consequently, the pride felt by individuals who belonged to the fisher community was replaced by a deep sense of alienation, in which occupationally displaced fishers felt they no longer belonged to either world, neither Chilika nor the city in which they worked as migrant laborers (Robson and Nayak 2010).

In the social-ecological setting of Chilika, economic development had serious implications for interhousehold equity. As fishing became capital intensive, and therefore expensive, it led to the exclusion of poorer households from fishing, thus widening the gap between rich and poor households. Poor, landless households could not diversify into other nonfishing activities because of the absence of financial capital. As a result, whereas the richer households tried to initiate small businesses, e.g., retail grocery shops, or convenience shops at nearby tourist locations, as part of their diversification strategy, the poorer households primarily opted for a daily wage, even if that meant outmigration.

\section{Institutional and political dynamics}

Elite capture of customary fishing areas through encroachment acted as a vehicle for the growth of aquaculture in Chilika. People in higher castes, those who were economically influential and linked to the state bureaucracy and political circles, took control of the lagoon. Of the 86 lease-eligible villages, 79 had customary fishing areas under active encroachment, whereas 81 of them reported their area to be either partially or completely lost. The locus of decision making and fishery management control gradually moved from the fishers to the powerful elites. 
Consequently, serious issues around fishers' access rights and entitlements emerged, which, in several cases, resulted in court proceedings. Ultimately, even though the provincial and federal courts ruled in favor of fishers' rights in Chilika and banned aquaculture, conservative estimates have put the total lagoon fishing area under illegal aquaculture at 60-80\% (Nayak and Berkes 2011). Changes in the ecological, social, economic, and political spheres have contributed to a steady process of institutional decay. It is the fisher villages and Chilika regional level institutional arrangements that have been most affected. As fish production dropped, about $90 \%$ of village fish cooperatives became inactive, and a process of constant weakening of smallerscale institutions followed. The creation of the FISHFED and CDA represented top-down control, which overwhelmed earlier bottom-up institutional processes, and a clear absence of linkages between the different institutional levels effectively created a vacuum. Table 3 lists these major institutional changes in Chilika as an outcome of social-ecological and economic influences.

\section{DISCUSSION}

\section{Two-way linkages: economic history and social-ecological processes}

Economic and livelihood activities under intensification and extensification strategies had a direct impact on the ecology of the lagoon and caused further degradation in resource conditions: a factor that had the potential to strongly decrease the quality of the lives of the fishers. A set of intensification strategies resulted in the alteration of fish seasonality and lack of attention to fish breeding periods, bringing key fish habitats under exhaustive fishing activities, all of which contributed to an amplification of the existing fluctuations in fish environments. Fishing behavior changed to capture fish of all sizes when fishers abandoned the customary norm of releasing small-sized catch. More postlarval fish were destroyed while picking postlarval shrimp for aquaculture ponds. Target species and scarce fish resources were both overfished, and this had a negative impact on both fish stock and production. Such outcomes exerted pressure on species composition, altered the spatial distribution of fish, and disturbed the lagoon food chain. Thus intensification in Chilika has led to a situation of 'fishing down the food chain' (Pauly et al. 1998), ultimately contributing to adverse ecological changes.

With intensification, there was a significant change in the customary fishing methods and techniques because synthetic gill nets and trammel nets were gradually introduced beginning in the 1980s. Many fishers link the use of synthetic nets to aquaculture, which used similar fishing gears. Not only did fishers stop using a diversity of fishing nets, but also more importantly, they stopped making them locally and became dependent on the market for synthetic nets, which most fishers found difficult to buy in the cash-strapped local economy. Moreover, a steady loss of fishingrelated traditional skill sets ensued, so that the knowledge of how to prepare a variety of fishing gear that was socially and ecologically appropriate was lost. This initiated a wider process of loss of other traditional skills, coupled with growing dependence on external market forces.

Uninterrupted aquaculture consistently had an impact on the lagoon ecosystem and its interlinked social structures, because shrimp aquaculture activities had multiple social-ecological influences. In response to the survey question on the adverse impacts of shrimp aquaculture either on the lagoon or on fishing activities, 135 fisher villages, out of 138 who responded, replied that they were subjected to adverse impacts. Aquaculture has led to chemical pollution in the lagoon as well as encroachment on important fish habitats, thereby limiting the fish feeding and breeding grounds, affecting fish stock, and catch size. Encroachment has also resulted in shrinkage of the lagoon fishing area, which in turn has led to serious concerns over fishers' access to both the scarce fish stock and fishing areas. More than $90 \%$ of fisher villages with lease rights reported loss of their customary fishing areas, with that loss ranging from $10-100 \%$ of the total area having gone to powerful shrimp mafias. In addition, extensification strategies have pushed fishers beyond their customary fishing boundaries and initiated competition for capturing strategic fishing areas, which has contributed to an overall increase in the instances of intervillage conflicts. Under economic pressure, fisher villages now largely disregard once agreed-upon boundary rules that had laid the foundation for commons formation in Chilika. The resulting situation is indicative of an open access regime and a trend toward the decommonization of fishery resources (Nayak and Berkes 2011).

Although fewer options for livelihood diversification can make households economically vulnerable, a similar tendency was observed even when households did diversify livelihood activities. For many fisher households, the move from fishing to fish vending meant a change from being an entrepreneur to accepting a form of wage employment. Other households that took up both the outmigration option and seasonal jobs as tourist boat drivers, considered these nonfishing activities as pushing them away from the lagoon, a form of disconnection as a result of their physical separation from 'Mother Chilika.' Studies elsewhere have shown that diversification is a desired strategy that could help in situations of livelihood crisis (Marschke 2005, Ta 2010). However, livelihood diversification becomes impossible in the absence of natural and financial capitals or may produce only limited results (Nayak 2011). High rates of outmigration in Chilika have led to large numbers of absent fishers, who fear that long absence from the lagoon may eventually weaken their fishing rights, not only in terms of their individual or household rights, but also their stake in the lagoon as a collective. Despite the fact that incomes from outmigration are not particularly rewarding, the poor status of fishers and their livelihood conditions either remain unchanged or worsen unless they outmigrate.

\section{Fishers' disconnection from the lagoon environment}

From a social-ecological system's point of view, the major impact of changes in Chilika concerns the alienation of traditional fishers from their lagoon. Nayak and Berkes (2012) explain alienation as a process of disconnection through the destruction of the physical, psychological, economic, and political relationship of people with their environment, which may result from loss of access and tenure rights, loss of livelihoods, outmigration, and loss of environmental knowledge and sense of stewardship. My study emphasizes this disconnection, pointing out that ecological degradation has a tendency to separate the population that has depended on the local resource environment for economic and cultural needs for its well-being. Inversely, changes in local economies and livelihoods often have adverse implications for ecosystem health. In Chilika, for example, growing dependence 
on external market forces and the loss of traditional skills both contributed to the process of alienation of fisher communities. The general village survey indicated that all customary fisher villages, except one, felt that their relationship with the lagoon had become weak, and they were in the process of being disconnected from it.

\section{CONCLUSIONS}

Chilika is a good case study from which to understand how changes in the ecological subsystem of the lagoon had profound impacts on the social and economic lives of the fishers. It demonstrated that, as the ecosystem was adversely affected by various drivers of change, this flowed over into other related systems linked to the fishers' social, economic, political, and cultural lives and generated a set of cascading negative impacts. In turn, changes in the social subsystem, e.g., local economy and social-political structures, influenced a number of changes in the ecological subsystem. Thus, loss of ecological capital had a direct impact on economic capital in the fisher communities and that in turn eventually weakened the level of their social and political capital. According to NRC (2000) ecological capital represents ecosystem processes and conditions that yield social and ecological services and it cites species diversity, for example, as an indicator of ecological capital. Relevant to my discussion, it can be seen as a unique and important component of the entire natural endowment that supports, protects, and is used by economic systems as a way to establish connections between humans and nature (Barbier 2011, Swagemakers and Wiskerke 2011).

Drivers across multiple scales, e.g., temporal, spatial, and functional, actively influenced the social-ecological system of Chilika. The global shrimp market and the international price for tiger prawn acted synergistically with hydrological intervention, i.e., the sea mouth, at the local and regional levels to create a set of complex results. Uncertainties in the biophysical system were evident in the nature of variability and unpredictability in the seasonal processes associated with the lagoon. Monoculture to boost high value product, such as tiger prawn, largely replaced a biodiversity of low value species that not only supported the local economy built around fishers' livelihoods, but also helped sustain the ecosystem. Disintegration of the livelihood system and dwindling incomes led to occupational displacement of fishers and outmigration. Fishing area encroachment by aquaculture interests resulted in frequent resource disputes, caste conflicts between fishers and nonfishers, and court cases resulting in serious implications for property rights and resource access regimes, with implications for fishing economy. The integrated nature of ecosystem processes and economic initiatives is striking in Chilika. The ecological advantages of the lagoon and its potential for intensive resource exploitation, economic profits for some, and revenue for the state have all shaped the history of Chilika to the present day. The history of economic change has remained a product of the ongoing social-ecological processes, which is shown to be a two-way process. Factors associated with changes in the local fishing economy also had social components as well as ecological dynamics. It is clear, for example, that the lagoon could have boasted a stronger fishing economy during the times when the ecological system was in a better shape. It is also clear that the course of economic history evolved with changes in the lagoon's social-ecological system.
Alienation of the fishers from their lagoon environment is one of the major outcomes of the changes in Chilika and has resulted from dysfunctional biophysical processes, loss of livelihood and income avenues, cultural disintegration linked to fishing as a caste identity, and political and institutional incapacitation of the fishers. This combination of factors shows that humanenvironment disconnection in Chilika traversed economic, social, ecological, and political boundaries and was shaped by crossinfluence among multiple components within the socialecological system. Connections between the components of the ecological and human subsystems (Nayak 2011) has been emphasized as a relationship between ecosystem services and human well-being (MEA 2005) and as an interaction of people with their environment that operate together to ensure sustainability (Kates et al. 2001, Clark and Levin 2010). At a global level, many countries that have poor environmental policies and a history of ecological degradation harbor large populations affected by poverty, hunger, lack of minimum income, and acute shortage of life's basic necessities. The reverse of this may be true in cases in which ecological collapse can be triggered by degradation in the economic system. It is thus vitally important to understand that economic history is integral to socialecological processes with which it shares interdependent trajectories and operates in a feedback loop, and this can be seen as a two-way interactive process in terms of their cross-influences. The economic history, as part of the social subsystem, is embedded within the social-ecological history, just as the economic dimension is embedded within the social-ecological, or human-environment, system.

The Chilika study showed that lagoons are complex socialecological systems and, hence, different aspects linked to their social and ecological dimensions cannot be separated from each other. A social-ecological approach is, thus, an appropriate way to understand the integrated nature of economic, social, political, and ecological components of the human-environment system and to understand the critical interplay among them. Unrestrained economic activities, such as aquaculture, have a tendency to tear the ecological wealth, political rights, cultural identity, and social well-being away from individuals and societies. Ecological and politics-driven interventions, such as the opening of the sea mouth in Chilika, can easily translate into the collapse of local economies and have numerous effects on ecosystem, culture, and society. It is only through an understanding of the combined dynamics, both complementarities and contradictions, among the various components of the social-ecological system that policy makers can provide appropriate ways to achieve overall sustainability.

Responses to this article can be read online at: http://www.ecologyandsociety.org/issues/responses. $\mathrm{php} / 5978$

\section{Acknowledgments:}

This work was undertaken as part of a panel, The Recent History and Practice of Small-scale Fisheries in a Globalising World, at the World Economic History Congress (WEHC) 2012, Stellenbosch, 
South Africa. I appreciate the contributions and insights from the special issue editors Rosemary Ommer and Barbara Paterson. Thanks to Tony Charles and one anonymous reviewer for their thoughtful and very helpful comments. I would like to thank the fishers of Chilika Lagoon for their unconditional friendship, support, and collaboration. This research is funded by the Social Sciences and Humanities Research Council (SSHRC) of Canada's grant to Prateep Nayak. Additional funding has been provided by the University of Waterloo through the Office of the Provost and the Canada Excellence Research Chair (CERC) in Ecohydrology.

\section{LITERATURE CITED}

Barbier, E. B. 2011. Scarcity and frontiers: how economies have developed through natural resource exploitation. Cambridge University Press, Cambridge, UK.

Béné, C. 2005. The good, the bad and the ugly: discourse, policy controversies, and the role of science in the politics of shrimp farming development. Development Policy Review 23(5):585-614. http://dx.doi.org/10.1111/j.1467-7679.2005.00304.x

Berkes, F. 2011. Restoring unity: the concept of marine socialecological systems. Pages 9-28 in R. E. Ommer, R. I. Perry, K. Cochrane, and P. Cury, editors. World fisheries: a social-ecological analysis. Blackwell, Brighton, UK. http://dx.doi.

org/10.1002/9781444392241.ch2

Berkes, F., and C. Folke, editors. 1998. Linking social and ecological systems: management practices and social mechanisms for building resilience. Cambridge University Press, Cambridge, UK.

Charles, A. T. 1995. Fishery science: the study of fishery systems. Aquatic Living Resources 8:233-239. http://dx.doi.org/10.1051/ alr:1995023

Charles, A. T. 2001. Sustainable fishery systems. Wiley-Blackwell, Oxford, UK. http://dx.doi.org/10.1002/9780470698785

Charles, A. T. 2005. Toward sustainable and resilient fisheries: a fishery-system approach to overcoming the factors of unsustainability. Pages 221-233 in J. Swan and D. Greboval, editors. Overcoming factors of unsustainability and overexploitation in fisheries: selected papers on issues and approaches. FAO Fisheries Report, No.782. Food and Agriculture Organization of United Nations, Rome, Italy. [online] URL: http://www.fao.org/ docrep/009/a0312e/A0312E13.htm\#ch2.11

Charles, A. T. 2007. Adaptive co-management for resilient resource systems: some ingredients and the implications of their absence. Pages 83-102 in D. Armitage, F. Berkes, and N. Doubleday, editors. Adaptive co-management: collaboration, learning, and multi-level governance. UBC Press, Vancouver, British Columbia, Canada.

Charles, A. T., M. Wiber, K. Bigney, D. Curtis, L. Wilson, R. Angus, J. Kearney, M. Landry, M. Recchia, H. Saulnier, and C. White. 2010. Integrated management: a coastal community perspective. Horizons 10:26-34. [online] URL: http://smu-facweb. smu.ca/ charles/PDFS_2005/094.pdf
Christie, P. 2011. Creating space for interdisciplinary marine and ecological research: five dilemmas and suggested resolutions. Environmental Conservation 38(2):172-186. http://dx.doi.org/10.1017/ S0376892911000129

Clark, W. C., and S. A. Levin, editors. 2010. Toward a science of sustainability: executive summary. Report from 'Toward a science of sustainability' conference, Warrenton, Virginia, USA. CID Working Paper No. 196. Center for International Development, Harvard University, Boston, Massachusetts, USA. [online] URL: http://scimaps.org/atlas/images/Towards a Science of Sustainability. pdf

Coulthard, S. 2008. Adapting to environmental change in artisanal fisheries: insights from a South Indian lagoon. Global Environmental Change 18(3):479-489. http://dx.doi.org/10.1016/ j.gloenvcha.2008.04.003

Crocker, T. D. 1999. A short history of environmental and resource economics. Pages 32-45 in J. C. J. M. van den Bergh, editor. Handbook of environmental and resource economics. Edward Elgar, Northampton, Massachusetts, USA. http://dx. doi.org/10.4337/9781843768586.00011

Daily, G. C. 1997. Nature's services: societal dependence on natural ecosystems. Island, Washington, D.C., USA.

Dale, V. H., S. Brown, R. A. Haeuber, N. T. Hobbs, N. Huntly, R. J. Naiman, W. E. Riebsame, M. G. Turner, and T. J. Valone. 2000. Ecological principles and guidelines for managing the use of land. Ecological Applications 10:639-670. http://dx.doi. org/10.1890/1051-0761(2000)010[0639:EPAGFM]2.0.CO;2

Das, M. N., editor. 1977. Sidelights on history and culture of Orissa. Vidhyapuri, Cuttack, India.

Delgado, C. L., N. Wada, M. W. Rosegrant, S. Meijer, and M. Ahmed. 2003. Outlook for fish to 2020: meeting global demand. International Food Policy Research Institute, Washington, D.C., USA and WorldFish Center, Penang, Malaysia.

Desai, W. S. 1961. A pageant of Burmese history. Orient Longmans, New Delhi, India.

Food and Agriculture Organization of the United Nations (FAO). 2006. FishStat Plus. Food and Agriculture Organization of the United Nations, Rome, Italy. [online] URL: http://www.fao.org/ fi/statist/fisoft/fishplus.asp

Folke, C., T. Hahn, P. Olsson, and J. Norberg. 2005. Adaptive governance of social-ecological systems. Annual Review of Environment and Resources 30:441-473. http://dx.doi.org/10.1146/ annurev.energy.30.050504.144511

Garcia, S. M., and A. T. Charles. 2008. Fishery systems and linkages: implications for science and governance. Ocean and Coastal Management 51:505-527. http://dx.doi.org/10.1016/j. ocecoaman.2008.05.001

Glaser, M. 2006. The social dimensions in ecosystem management: strengths and weaknesses of human-nature mind maps. Research in Human Ecology 13:122-142. [online] URL: http://www.humanecologyreview.org/pastissues/her132/glaser.pdf 
Gómez-Baggethun, E., R. de Groot, P. L. Lomas, and C. Montes. 2010. The history of ecosystem services in economic theory and practice: from early notions to markets and payment schemes. Ecological Economics 69:1209-1218. http://dx.doi.org/10.1016/j. ecolecon.2009.11.007

Halpern, B. S., S. Walbridge, K. A. Selkoe, C. V. Kappel, F. Micheli, C. D’Agrosa, J. F. Bruno, K. S. Casey, C. Ebert, H. E. Fox, R. Fujita, D. Heinemann, H. S. Lenihan, E. M. P. Madin, M. T. Perry, E. R. Selig, M. Spalding, R. Steneck, and R. Watson. 2008. A global map of human impact on marine ecosystems. Science 319(5865):948-952. http://dx.doi.org/10.1126/science.1149345

Holling, C. S. 2001. Understanding the complexity of economic, ecological and social systems. Ecosystems 4:390-405. http://dx. doi.org/10.1007/s10021-001-0101-5

Jentoft, S., and R. Chuenpagdee. 2009. Fisheries and coastal governance as a wicked problem. Marine Policy 33:553-560. http://dx.doi.org/10.1016/j.marpol.2008.12.002

Kates, R., W. C. Clark, R. Corell, J. M. Hall, C. C. Jaeger, I. Lowe, J. J. McCarthy, H. J. Schellnhuber, B. Bolin, N. M. Dickson, S. Faucheux, G. C. Gallopin, A. Grübler, B. Huntley, J. Jäger, N. S. Jodha, R. E. Kasperson, A. Mabogunje, P. Matson, H. Mooney, B. Moore, III, T. O'Riordan, and U. Svedin 2001. Sustainability science. Science 292:641-642. http://dx.doi.org/10.1126/science.1059386

Khan, A. S., and B. Neis. 2010. The rebuilding imperative in fishery: clumsy solutions for a wicked problem? Progress in Oceanography 87:347-356. http://dx.doi.org/10.1016/j.pocean.2010.09.012

Kotchen, M., and O. Young. 2007. Meeting the challenges of the anthropocene: towards a science of coupled human-biophysical systems. Global Environmental Change 17:149-151.

Kurien, J. 1992. Ruining the commons and responses of the commoners: coastal overfishing and fishermen's actions in Kerala State, India. Pages 221-258 in D. Ghai and J. Vivian, editors. Grassroots environmental action: peoples participation in sustainable development. Routledge, London, UK.

Lobe, K., and F. Berkes. 2004. The padu system of communitybased fisheries management: change and local institutional innovation in south India. Marine Policy 28(3):271-281. http://dx. doi.org/10.1016/S0308-597X(03)00087-3

Ludwig, D., M. Mangel, and B. Haddad. 2001. Ecology, conservation, and public policy. Annual Review of Ecology and Systematics 32:481-517. http://dx.doi.org/10.1146/annurev. ecolsys. 32.081501 .114116

Mahon R., P. McConney, and R. N. Roy. 2008. Governing fisheries as complex adaptive systems. Marine Policy 32:104-112. http://dx.doi.org/10.1016/j.marpol.2007.04.011

Marschke, M. 2005. Livelihood in context: learning with Cambodian fishers. Disssertation. University of Manitoba, Winnipeg, Manitoba, Canada. [online] URL: https://umanitoba. ca/institutes/natural resources/canadaresearchchair/thesis/mmarschke $\%$ 20phd $\% 20$ thesis $\% 202005$.pdf

Marshall, J. 2001. Landlords, leaseholders, and sweat equity: changing property regimes in aquaculture. Marine Policy 25:335-352. http://dx.doi.org/10.1016/S0308-597X(01)00020-3
Millennium Ecosystem Assessment (MEA). 2003. Ecosystems and human well-being: a framework for assessment. Chapter 5: dealing with scale. Pages 107-147 in Millennium ecosystem assessment. Island, Washington, D.C., USA. [online] URL: $\underline{\text { http:// }}$ www.unep.org/maweb/documents/document.303.aspx.pdf

Millennium Ecosystem Assessment (MEA). 2005. Ecosystems and human well-being: general synthesis. Pages in Millennium ecosystem assessment. Island, Washington, D.C., USA. [online] URL: http://www.unep.org/maweb/en/Synthesis.aspx

National Research Council (NRC). 2000. Ecological indicators for the nation. National Academy, Washington, D.C., USA.

Nayak, P. K. 2011. Change and marginalisation: livelihoods, commons institutions and environmental justice in Chilika Lagoon, India. Dissertation. University of Manitoba, Winnipeg, Manitoba, Canada. [online] URL: http://mspace.lib.umanitoba. ca/bitstream/1993/5032/1/NAYAK\%20PRATEEP \%20Doctoral $\%$ 20Thesis.pdf

Nayak, P. K., and F. Berkes. 2010. Whose marginalisation? Politics around environmental injustices in India's Chilika Lagoon. Local Environment 15:553-567 http://dx.doi.org/10.1080/13549839.2010.487527

Nayak, P. K., and F. Berkes. 2011. Commonisation and decommonisation: understanding the processes of change in Chilika Lagoon, India. Conservation and Society 9:132-145. http://dx.doi.org/10.4103/0972-4923.83723

Nayak. P. K., and F. Berkes. 2012. Linking global drivers with local and regional change: a social-ecological system approach in Chilika Lagoon, Bay of Bengal. Regional Environmental Change Nov. 2012. http://dx.doi.org/10.1007/s10113-012-0369-3

Neiland, A. E., N. Soley, J. B. Varley, and D. J. Whitmarsh. 2001. Shrimp aquaculture: economic perspectives for policy development. Marine Policy 25:265-279. http://dx.doi.org/10.1016/ $\underline{\mathrm{S} 0308-597 X(01) 00017-3}$

O’Malley, L. S. S. 1908. Bengal district gazetteers: Puri. Logos, New Delhi, India.

Ommer, R. E. 2007. Coasts under stress: restructuring and socialecological health. McGill-Queen's University Press, Kingston, Ontario, Canada.

Patra, B. 2005. Kalinga and Burma: a study in ancient relations. Orissa review 1:24-30. [online] URL: http://orissa.gov.in/emagazine/Orissareview/nov2005/engpdf/Kalinga_and_Burma-A_Study \% 20in_\%20Ancient_Relations.pdf

Patra, S. K., and B. Patra. 1993. Archaeology and the maritime history of Ancient Orissa. OHR XLVII(2):107-118. [online] URL: http://orissa.gov.in/e-magazine/Journal/Journal2/pdf/ohrj-014. pdf

Pattnaik, A. K. 2003. Phytodiversity of Chilika Lake, Orissa, India. Dissertation. Utkal University, Bhubaneswar, India.

Pattnaik, S. M., and N. Mehrotra. 2006. The politics of water: lake, people and the state. Pages 189-194 in S. K. Chaudhury, editor. Culture, ecology, and sustainable development. Mittal, New Delhi, India. 
Pattanâyaka, P. K. 1979. A forgotten chapter of Orissan history (with special reference to the Rajas of Khurda and Puri 1568-1828). Punthi Pustak, Cuttack, India

Pauly, D., V. Christensen, J. Dalsgaard, R. Froese, and F. Torres, Jr. 1998. Fishing down marine food webs. Science 279:860-863. http://dx.doi.org/10.1126/science.279.5352.860

Perrings, C., and B. Walker. 1995. Biodiversity loss and the economics of discontinuous change in semiarid rangelands. Pages 190-210 in C. Perrings, K. G. Maler, C. Folke, C. S. Holling, and B. O. Jansson, editors. Biodiversity loss: economic and ecological issues. Cambridge University Press, Cambridge, UK. http://dx. doi.org/10.1017/CBO9781139174329.009

Pradhan, D., and M. Flaherty. 2008. National initiatives, local effects: trade, liberalization, shrimp aquaculture, and coastal communities in Orissa, India. Society and Natural Resources 21:63-76. http://dx.doi.org/10.1080/08941920701655734

Rana, K. J., R. Grainger, and A. Crispoldi-Hotta. 1998. Current methods and constraints for monitoring production from inland capture fisheries and aquaculture. Pages 169-181 in T. Petr, editor. Inland fishery enhancements. FAO Fisheries Technical Paper T374. Food and Agriculture Organization of the United Nations, Rome, Italy. [online] URL: http://www.fao.org/docrep/005/ $\underline{\mathrm{w} 8514 \mathrm{e} / \mathrm{W} 8514 \mathrm{E} 11 . h \mathrm{tm} \# \mathrm{ch} 10}$

Ray, B. C. 1960. Orissa under Marathas, 1751-1803. Kitab Mahal, Cuttack, India.

Ray, B. C. 1981. Orissa under the Mughals - from Akbar to Alivardi: a fascinating study of the socio-economic and cultural history of Odisha. Punthi Pustak, Calcutta, India.

Rittel, H. W. J., and M. M. Weber. 1973. Dilemmas in general theory of planning. Policy Science 4:155-169. http://dx.doi. org/10.1007/BF01405730

Robson, J. P., and P. K. Nayak. 2010. Rural out-migration and resource-dependent communities in Mexico and India. Population and Environment 32:263-284. http://dx.doi.org/10.1007/ $\underline{\text { s11111-010-0121-1 }}$

Sinha, B. K. 2000. Golabai: a protohistoric site on the coast of Orissa. Pages 322-355 in K. K. Basa and P. Mohanty, editors. Archaeology of Orissa. Vol. I. Pratibha Prakashan, Delhi, India.

Steffen, W., R. A. Sanderson, P. D. Tyson, J. Jäger, P. A. Matson, B. Moore, III, F. Oldfield, K. Richardson, H.-J. Schellnhuber, B. L. Turner, and R. J. Wasson. 2004 Global change and the Earth system: a planet under pressure. Springer-Verlag, Berlin, Germany.

Swagemakers, P., and J. S. C. Wiskerke. 2011. Revitalizing ecological capital. Geografisk Tidsskrift-Danish Journal of Geography 111(2):149-167. http://dx.doi.org/10.1080/00167223.$\underline{2011.10669530}$

Ta, T. T. H. 2010. Resource access and livelihood resilience in Tam Giang Lagoon, Vietnam. Dissertation. University of Manitoba, Winnipeg, Manitoba Canada. [online] URL: http://mspace.lib. umanitoba.ca/handle/1993/3999

Turner, II, B. L., P. A. Matson, J. J. McCarthy, R. W. Corell, L. Christensen, N. Eckley, G. K. Hovelsrud-Broda, J. X. Kasperson,
R. E. Kasperson, A. Luers, M. L. Martello, S. Mathiesen, R. Naylor, C. Polsky, A. Pulsipher, A. Schiller, H. Selin, and N. Tyler. 2003. Illustrating the coupled human-environment systems for vulnerability analysis: three case studies. Proceedings of the National Academy of Sciences 100(14):8080-8085. http://dx.doi. org/10.1073/pnas. 1231334100

Vasudevappa, C., and D. Seenappa. 2002. Literature review of shrimp farming in India. Individual partner report for the project: policy research for sustainable shrimp farming in Asia. European Commission INCO-DEV Project PORESSFA No. IC4-2001-10042. Centre for the Economics and Management of Aquatic Resources (CEMARE), University of Portsmouth, Portsmouth, UK and Fisheries Research Station (FRS), University of Agricultural Sciences, Bangalore, India. [online] URL: http://www.port.ac.uk/ research/cemare/publications/pdffiles/sustainableshrimpfarminginasia/ filetodownload,28777,en.pdf

Walker, B., S. Carpenter, J. Anderies, N. Abel, G. S. Cumming, M. Janssen, L. Lebel, J. Norberg, G. D. Peterson, and R. Pritchard. 2002. Resilience management in social-ecological systems: a working hypothesis for a participatory approach. Conservation Ecology 6(1): 14. [online] URL: http://www. consecol.org/vol6/iss1/art14/

Waltner-Toews, D., and J. Kay. 2005. The evolution of an ecosystem approach: the diamond schematic and an adaptive methodology for ecosystem sustainability and health. Ecology and Society 10(1): 38. [online] URL: http://www.ecologyandsociety. org/vol10/iss1/art38/

Westley, F., S. R. Carpenter, W. A. Brock, C. S. Holling, and L. H. Gunderson. 2002. Why systems of people and nature are not just social and ecological systems. Pages 103-119 in L. Gunderson and C. S. Holling, editors. Panarchy: understanding transformations in human and natural systems. Island, Washington, D.C., USA. 